\title{
Pellicer de Ossau: una visión de la monarquía católica entorno a 1640
}

\author{
Raquel martín Polín *
}

\begin{abstract}
RESUMEN
El momento de crisis para la Monarquía Católica al que condujeron las rebeliones de Cataluña y Portugal en 1640, se convirtió en uno de los contextos más propicios para que los polemistas al servicio de Felipe IV se alineasen bajo un discurso del que era fundamento una visión del mundo en clave religiosa. Pellicer de Ossau fue un autor más entre ellos, pero sus obras no sólo llevarían tal discurso hasta sus últimas consecuencias sino que, además, lo dotarian de una fuerte impronta castellana.

ABSTRACT

The critical moment for the Catholic Monarchy generated by the Catalonian and Portuguese revolts of 1640 , became into one of the most favorable opportunities for the debaters at the service of Philip IV to join forces in defending a whole philosophy, based on a religious point of view of the world. Pellicer de Ossau was yet another one of them and his works would not only take this philosophy to its ultimate consequences, but would also give it a strong Castillian impression.
\end{abstract}

En 1641 José Pellicer en el Argumento de su Astrea Safica definía a Felipe IV como "Principe que Reina mas en los coraçones que en las Ciudades; siendo primero señor absoluto de las voluntades que de los Pueblos"' ?.

* Uriversidad Autónoma de Madrid.

1 Pellicer de Ossau, J. La Astrea Safica. Panegirico al Gran Monarca delas Españas i Nuevo Mundo en que recopila los Mayores Sucessos de su Felicissimo Reinado, hasta el Año MDCXXXV. Zaragoza, 1641, pp. 22-23. Parece que la obra tendría una segunda parte titulada Nemesis Catolica, pero no hay rastro de que se hubiese publicado. 
Tras esas palabras, como intentaremos ver en las siguientes páginas, se escondía una peculiar comprensión, de matriz castellana, de la relación entre rey y súbditos, de lo que debía ser y era la Monarquía Hispana y, en definitiva, toda una visión del mundo esencialmente religiosa y católica que en un momento de crisis como fue la década de los cuarenta parecía necesario recordar.

Poco es lo que sabemos sobre la vida de José Pellicer de Ossau y Tovar. Nacido en Zaragoza en 1602, llegaría a ser un personaje de cierta importancia en la corte de Felipe IV, desempeñando el cargo de Cronista del Rey en la Corona de Aragón, que obtuvo en 1640. Según los datos que Enrique Tierno Galván aporta en su conocido libro de Avisos ${ }^{2}$, Pellicer realizó una amplia labor como polemista al servicio de la Monarquía, pero sin que podamos encuadrar su discurso en el de un jurista o un teólogo ya que, pese a los estudios en derecho en la Universidad de Salamanca que el autor se atribuía, parece que nunca llegó a culminarlos.

Entre el abultado número de obras que Pellicer produjo a lo largo de su vida no faltó, junto con las genealogías de nobles que le permitían sustentarse, una buena parte que respondería tanto a su cargo de Cronista como a su innegable militancia política, claro está, en el frente de la Monarquía. En este sentido, resulta especialmente interesante su producción en torno a 1640 cuando la Monarquía Católica vio unirse a sus problemas europeos las convulsiones internas de Cataluña y Portugal. Dos de las obras escritas en tales fechas serán las que nos ocupen especialmente en las próximas páginas, La Astrea Safica y la ldea del Principado de Cataluña.

En guerra con Francia desde 1635 y con una Europa sacudida por la Guerra de los Treinta Años desde 1618, parecia imposible intentar mantener el binomio reformación interior-reputación exterior pretendido por la política de Olivares. El elevado coste de la actuación bélica de la Monarquía unida a la precaria situación económica de la misma acabarían creando una situación insostenible que no tardó en estallar. Cataluña, remisa ya desde 1626 al proyecto de Unión de Armas del valido de Felipe IV, se vio obligada a albergar desde 1635 a las tropas que presentaban frente a Francia; los lógicos problemas derivados de ello junto con las fuertes tensiones internas de una sociedad catalana muy fragmentada (y cada vez con menos expectativas económicas en el Mediterráneo) terminarian saliendo a la luz aprovechando la confusión de las fiestas del Corpus Christi

2 Tierno Galvan, E., Avisos históricos. Madrid, 1975. Asimismo, queda ampliamente registrado su perfil como polemista en ia obra de JOVER, J. M., 1635. Historia de una polémica y semblanza de una generación. Madrid, 1949. 
de 1640. El Principado de Cataluña se convertía de este modo en la principal preocupación de la Monarquía; una Cataluña sublevada no sólo era peligrosa estratégicamente hablando (pues en lugar de ser tapón para Francia, podría servirle de cabeza de puente) sino que, como veremos, lo era, y mucho, para la propia esencia de la Monarquía Católica: la guerra con Cataluña también podría percibirse en términos de guerra de religión.

Apenas se había comenzado a reaccionar ante los sucesos catalanes de junio, cuando llegaban a la corte noticias de otro desastre. Portugal, que había permanecido en la Monarquía desde 1580, también se había sublevado aclamando desde diciembre como rey al Duque de Braganza. La situación crítica de la Monarquía, y muy especialmente los hechos catalanes, crearon el caldo de cultivo adecuado para el triunfo de la conspiración nobiliaria que conduciría a Joao IV al trono. Las causas que explicaban la situación portuguesa eran distintas a las de la catalana; aquí, a un claro descontento por la decadencia de la situación mercantil lusa (en gran parte debida al enfrentamiento de la Monarquía Católica con Holanda y a lo que Hespanha ha denominado "dilema geopolítico de la Monarquía») y a la escasa simpatía por la política de Olivares (que había quedado patente con los sucesos de Évora en 1637) se unían otras razones entre las que no serían las menos importantes el entendimiento de que la permanencia en la Monarquía pasaba por soportar medidas antiportuguesas que vulneraban el orden natural luso (como la introducción de juntas, la aplicación de la Unión de Armas...), o la propia conciencia de haber sido reino independiente sometido por la fuerza de las armas. Sin embargo, Madrid consideró el portugués un problema menor frente a la rebelión de los catalanes (quizá precisamente por lo que esta última suponia de ataque a los cimientos mismos de la Monarquía) centrando más las energías en la represión de la primera. Pese al éxito inicial de ambas revueltas, se trataba de dos problemas diferentes que tendrían distintos resultados; finalmente, Cataluña volvería al seno de la Monarquía en 1653, mientras que Portugal culminaba con éxito definitivo su Restauración. En medio quedaban unos años de crisis profunda en los que las plumas de los polemistas al servicio de la Monarquía trabajaron sin descanso ${ }^{3}$.

\footnotetext{
3 Para una visión global del reinado de Felipe IV Vid. Fernández Albaladejo, P., Actas de las Juntas del Reino de Galicia. Vol. II. 1630-1636. Galicia, 1997. Más concretamente sobre las alteraciones de Cataluña en 1640. ELLIOTT, J. H., La rebelión de los catalanes: un estudio sobre la decadencia de España (1598-1640). Madrid, 1977, y los más recientes trabajos de SerRA, E. (ed.), La revolució catalana de 1640. Barcelona, 1991, y SIMÓN : TARRES, A., Els origens ideologics de la revolució catalana de 1640. Barcelona, 1999. Para Portugal específiamente Vid. BouzA ÁLvAREZ, F. J., Portugal en la Monarquia Católica (1580-1640). Felipe Il. las Cortes de Tomar y la génesis del Portugal Católico. Madrid, 1987 y los estudios más claramente centrados en el momento de 1640
} 
Parece evidente que La Astrea Safica no pretendía ser una obra ambiciosa que diese respuesta a la difícil situación de 1640; se trataba sólo de una historia panegírica de los hechos del reinado de Felipe IV hasta 1635, fecha anterior a la de las crisis catalana y portuguesa. Sin embargo, la obra que se publicó en Zaragoza en $1641^{4}$ incluía una nueva dedicatoria a Don Pedro Fajardo Zúñiga y Requesens, Marqués de los Vélez, por entonces Virrey, Lugarteniente y Capitán General del Principado de Cataluña y los condados de Rosellón y Cerdaña. Podría pues sospecharse que dicha dedicatoria no tenía nada de inocente, especialmente si tenemos en cuenta que fue los Vélez quien estuvo al mando de las tropas que marcharon sobre Cataluña en 1640; más aún, curiosamente la dedicatoria firmada por Pellicer a 17 de noviembre de $1640{ }^{5}$ resultaba de lo más apropiada tan sólo unos días antes de la primera entrada de las tropas del rey en Cataluña pues, una semana más tarde, el 23 de noviembre, el Marqués de los Vélez encabezaba la ofensiva armada contra el Principado entrando en Tortosa.

No sólo en La Astrea Safica daría muestras Pellicer de su preocupación por la cuestión catalana. Entre sus reflexiones sobre el problema que se conservan en la Biblioteca Nacional, encontramos numerosas relaciones manuscritas (la mayor parte de ellas fechadas en 1642) que detallan la actuación del ejército real en el Principado ${ }^{6}$, así como distintas alusiones en las obras impresas de tales fechas. Posiblemente, la más importante al respecto sería su ldea del Principado de Cataluña de junio de 1642, en la que presentaba una historia de las alteraciones y movimientos de Cataluña a la luz de los hechos de $1640^{7}$.

Los problemas con Portugal fueron también tema de preocupación para Pellicer en estos años ocupándose de ellos en su breve Sucession de los

\footnotetext{
de Valladares, R., Felipe IV y la restauración de Portugal. Málaga, 1994 y La rebelión de Portugal: guerra, conflicto y poderes en la Monarquia Hispánica (1640-1680). Valladolid, 1998.

4 Manejamos una segunda edición de la misma añadida y enmendada. Parece que la primera, que no hemos podido hallar, se habría editado en Pamplona con dedicatoria al Príncipe Baltasar Carlos a fecha de 20 de enero de 1640 y, por tanto, antes de la revuelta catalana del mes de junio.

5 Y en la que se prodigaba en elogios al Virrey animándolo en su próxima empresa de pacificación con expresiones de apoyo tan claras como la siguiente: "O! Quiera el Cielo, que la Paz tan deseada para la Christiandad, se la deva a V.E.! Y que la lusticia maltratada por los Rusticos inquietos [esto es, los catalanes] buelva por V.E. a su primero Esplendor!s. Astrea..., p. 12.

6 Las relaciones a que nos referimos se encuentran en Mss. 11146.

7 Pellicer de Ossau, J., ldea del Principado de Cataluña, recopilacion de sus movimientos antiguos i modernos y examen de sus privilegios. Amberes, 1642. Se trata de una primera parte, de la que no conocemos continuación formada por cuatro libros en los que se ocupa de la historia catalana desde la fundación de Barcelona.
} 
Reynos de Portugal i El Algarve que publicó en Logroño el 18 de diciembre de 1640, casi inmediatamente después del nombramiento de Joao IV el primero de este mes, insistiendo en la justicia de los títulos que habían Ilevado a Felipe II a ser rey de Portugal ${ }^{8}$. Junto con estas obras claramente centradas en los conflictos catalán y luso, entre 1640 y 1642 (es decir, los años transcurridos entre la publicación de La Astrea Safica y la Idea del Principado de Cataluña) Pellicer publicaría otras obras de temática variada ${ }^{9}$ de las que en la Biblioteca nacional se conservan, teniendo especial interés para nuestro trabajo, la Fama Austriaca o Historia panegirica de la vida y hechos del Emperador Ferdinando Segundo en BarceIona en $1641^{10}$ y las Virtudes y vida espiritual de Ferdinando de Austria en Zaragoza en 1640 ". En estas últimas obras encontramos la confirmación

8 Pellicer de Ossau, J., Sucession de los Reynos de Portugal i El Algarve. Logroño, 1640. Según indica J. H. ELLIOTT («Portugal, Cataluña y la caída del Conde-Duque (1640-1643)»en Historia de España Ramón Menéndez Pidal. Vol. XXV. La España de Felipe IV. Madrid, 1986) Pellicer habria publicado el 30 de enero de 1640 otra obra reflexionando sobre los problemas de Portugal titulada El Comercio impedido y, por tanto, antes de que se produjese la revuelta. En ella Pellicer analizaba las causas de las dificultades del comercio español haciendo culpables de las mismas a los portugueses. J. H. Elliott cita la obra a partir del comentario y reproducción de alguno de sus fragmentos en SEMPERE y Guarinos, J., Biblioteca española económico-política. Tomo III. Madrid, 1804. Sin embargo, Sempere y Guarinos (que atribuye la obra a 1640 pero sin precisar más la fecha de publicación) afirma que El Comercio impedido sólo fue impreso dos veces apareciendo como obra anónima, aunque se conservaría un ejemplar firmado por Pellicer en la Biblioteca Real, del que no ha quedado rastro. Por el contrario, en la Biblioteca Nacional y precisamente en uno de los volúmenes de manuscritos de Pellicer sobre las alteraciones de Cataluña de 1640 (Mss. 11146), en el que se encuentran incluso algunos fragmentos de la ldea del Principado de Cataluña, aparece junto a los mismos un manuscrito (de caligrafía distinta a la del propio Pellicer) titulado Comercio Impedido, con fecha de 30 de enero de 1640 y que, pese a no estar firmado, concuerda iteralmente con las citas recogidas por Sempere y Guarinos. A pesar de que asi parecería confirmada la fecha de 1640 para la publicación de la obra, Nicolás Antonio en su Bibliotheca Hispano Nova (Madrid, 1783), sitúa la publicación del escrito en Madrid, 1639 (y precisa el título: El Comercio impedido por los enemigos ocultos de la Monarquía), fecha que confirma el propio Pellicer en su Biblioteca formada por los libros i obras publicas de Don loseph Pellicer de Ossau y Tobar (Valencia, 1671), dando el título de El Comercio Impedido por los Enemigos Desta Monarchia, afirmando también que la obra fue impresa por segunda vez en Sevilla pero sin nombre. De este modo, aunque tanto Sempere y Guarinos como J. $H$. Elliott atribuyen la impresión de la obra al año de 1640, no parece que la fecha pueda confirmarse con claridad pues no se conserva ningún ejemplar impreso localizado.

9 En la Biblioteca formada de los libros i obras publicas de Don loseph Pellicer de Ossau y Tobar publicada en Valencia en 1671 por uno de sus nietos, se recogen las obras manuscritas e impresas, publicadas e iréditas realizadas por Pellicer hasta 1671, con un suplemento y una adición al mismo que incluyen las obras hasta 1676. De la mayor parte que se citan como publicadas entre 1640 y 1642 no tenemos ninguna pista, sin que nos sea posible saber cuáles de ellas vieron ciertamente la luz, a excepción de las cinco que manejamos para nuestro trabajo.

10 Aunque la obra se publicase en está fecha, la censura más antigua es de 20 de noviembre de 1639 .

11 Por la dedicatoria sabemos que no se trata de una obra original de Pellicer, sino una traducción (aunque no del original en su integridad) de la obra del jesuita Guiliermo Lamormain, confesor del emperador, que Pellicer habría adaptado para que no se encontrase el castellano «careciendo desta preciosa semilla de exemplos" (p. 4 dorso). 
de las ideas que, tratadas de forma más explícita, empleó Pellicer para condenar las rebeliones catalana y portuguesa, ideas que como dijimos al principio eran imagen de una forma de ver el mundo.

Pero ¿trataba Pellicer de igual modo los casos catalán y portugués? Si bien es cierto que los esfuerzos del autor, como los de la Monarquia, se centraron más en refutar las razones alegadas por los sublevados en Cataluña, la única obra que hemos manejado en la que Pellicer reflexionó sobre Portugal parece responder a una línea de argumentación diferente ya que, mientras en Cataluña se trataba de demostrar la invalidez de los derechos que los sublevados consideraban había vulnerado la política de Olivares, en Portugal no se trataría el problema como una cuestión de fueros, sino de la auténtica legitimidad de los monarcas españoles frente a la casa de Braganza. Sin embargo, como intentaremos ver, bajo los distintos tratamientos de cada caso, subyacía un mismo discurso político y, por tanto, una misma forma de pensar, interpretar y actuar en tal campo, forma que, en el caso de nuestro autor, tenía una fortísima impronta castellana.

"O! quiera el Cielo, que...la lusticia maltratada por los Rusticos inquietos buelva por V.E. a su primero Esplendor! Para que aquella Gloriosissima Provincia se quiete, i no padezcan tan fieles Vasallos al odio de los sediciosos, Perturbadores el sosiego publico.... 12.

Así se dirigía Pellicer al Marqués de los Vélez antes de que éste iniciara su campaña en Cataluña. Los súbditos catalanes, en realidad siempre fieles, habían quebrantado la justa relación con su monarca natural y no parecía quedar más alternativa que acudir a las armas. Esta misma idea volvería a ser barajada por Pellicer en la ldea del Principado de $\mathrm{Ca}$ taluña, en cuyo comienzo el autor afirmaba que tres eran los géneros de castigos posibles para los delitos de los hombres: "o el remordimiento de la conciencia...o aquellos suplicios extraordinarios, i ocultos reservados a la mente de Dios...o las Leyes Severas" y añadia, "Creo Señor, que estos tres gèneros de castigos han de cooperar contra los movedores de las Alteraciones de Cataluña..." ${ }^{13}$. Resultaba así que el problema de los súbditos catalanes era un problema de conciencia, o más bien de ignorancia de la misma, ya que si había que acudir a la justicia del rey, es decir, a las leyes, era porque éstas «tienen por Oficio la Punicion de los Malhechores; que incorregibles al miedo de la Propia conciencia $i$ al Temor del Enojo de Dios, reinciden en sus insultos" ${ }^{14}$. Pero si el problema era de conciencia,

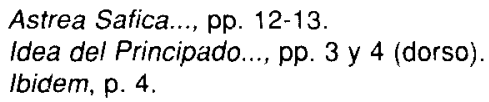


no podía explicarse en términos estrictamente jurídicos; la conciencia pertenecia a un ámbito que no era el del Derecho estricto. Quizá la falta de conciencia podía tener su castigo en la justicia defendida por el rey, pero explicar lo que esa falta de conciencia suponía remitía necesariamente, no al ámbito del Derecho, sino al de un lenguaje político común en Europa pero con especiales matices en la monarquía Católica; nos referimos al del Amor religiosamente concebido $\mathrm{y}$, por tanto, a un ámbito regido antes por Teología que por Derecho.

Al levantarse contra su rey, catalanes y portugueses habian hecho caso omiso de la conciencia, habian faltado al vínculo amoroso que les unía con el mismo y, más aún, la perseverancia en tal actitud suponia rechazar la clemencia del príncipe, esto es, su amor ${ }^{15}$; el recurso a la justicia estricta o el rigor del Derecho era ya la única alternativa posible, pero había sido la última. El amor era antes que el Derecho aunque, en última instancia, la aplicación de las leyes no dejase de ser una demostración de amor más, un acto caritativo. Como bien nos recuerda B. Clavero, el vínculo amoroso desigual entre rey y súbditos se entendía como expresión del orden amoroso emanado de Dios, vínculo de amor religiosamente entendido y, por ello, regido no por Derecho, sino por Teología ${ }^{16}$, de ahí que el último recurso ante los súbditos rebeldes fuese la justicia, el peso del Derecho.

Vínculo amoroso; se entiende así que Pellicer hablase de Felipe IV como "Principe que reina mas en los coraçones que en las Ciudades" ${ }^{17}$. Pero si el vínculo fundamental (que no único) que unía a rey y súbditos era de naturaleza amorosa, su relación no podía entenderse en términos políticos (al menos por lo que a tal vínculo se refería) sino económicos, esto es, familiares, propios de la relación entre padre e hijos. El rey era asi "padre económico de la familia constituida por su reino" ${ }^{18}$. Tenemos pues

15 "...siendo asi que quanto los catalanes han jdo redoblando delitos, ha ido su Magestad redoblando Benignidades con ellos, demostrando clementisimos afectos de su reduccion; como lo estan manifestando tantos papeles, edictos i Vandos como ha hecho divulgar por la Provincia, en particular el que se publico a Veinte i quatro de Enero deste Año, donde no tuvo mas que dar de si la Clemencia Real i el Amor de Principe...". Idea del Principado... La cita corresponde a la dedicatoria $A /$ Que Leyere del comienzo de la obra, pero por un error de edición sus páginas están desordenadas y sin numerar.

16 Clavero, B., Antidora. Antropología católica de la economía moderna. Milán, 1991.

17 Astrea Safica, p. 22. Para una mejor comprensión de la particular visión del mundo que venimos reseñando y sus consecuencias Vid. Fernández Albaladejo, P., "Católicos antes que ciudadanos: gestación de una "Política Española" en los comienzos de la Edad Moderna" en ForTEA PÉREZ, J. I. (ed.), Imágenes de la diversidad. El Mundo Urbano en la Corona de Castilla (siglos XVIxvili. Santander, 1997, pp. 103-127.

18 iñuaritegui, J. M., “Monarquía y Constitución» en Historiar, n. ${ }^{\circ}$ 1, 1999, pp. 8-18 (p. 10). 
una relación desigual, expresión de un amor que, incluyendo a Dios, ordenaba una sociedad ${ }^{19}$ cuya unidad esencial era la familia. Volverse contra el príncipe era hacerlo contra el padre; pero un padre debía ser clemente, amoroso y por ello Pellicer hablaría en el caso catalán de "la Tolerancia de su Magestad, en no averlos querido castigar como Rey Severo, sino encaminarlos como Padre Piadoso" 20.

Pero no hay que llamarse a engaño, el vínculo amoroso entre rey y súbditos comportaba una obligación de obediencia aún más fuerte que la que pudiese establecer el Derecho, pues apelaba a la conciencia y, con ella, a la religión. Si el orden constitucional imitaba un orden universal diseñado por Dios ${ }^{21}$, el vínculo amoroso entre rey y súbditos no dejaba de ser una reproducción terrena del vínculo también amoroso y también desigual entre Dios y los hombres; al amor del príncipe, como al amor de Dios, no se le podía corresponder en grado de igualdad, sino de proporción, y esa correspondencia era naturalmente obligada ${ }^{22}$. ¿Quién sino un monstruo podía volverse contra el amor del rey? Si la república era, se debía al amor del soberano que se despojaba de sí mismo para consagrarse a la misma; sólo asi, mediante el amor regio podía ser el cuerpo político. La gracia y servicio reales eran, de este modo, muestras de ese amor sin medida. Pero el amor exigía ser correspondido y más aún cuando existía desigualdad entre los amantes, pues entonces la deuda generada era permanente, infinita ${ }^{23}$. Quebrantar el vínculo de amor con el rey resultaba así un acto execrable no sólo para la conciencia, sino peligroso en lo político: si la república era por amor del príncipe, faltar a ese amor era atacar al bien de la república misma.

Por otra parte, acabamos de afirmar que el propio orden jurídico se percibía como reflejo de ese orden natural trazado por Dios y si eso era así, a la Teología antes que al Derecho competían las relaciones entre los hombres, tanto las reguladas por las leyes humanas como aquellas que, por amorosas, trascendían el ámbito del Derecho estricto. Era este un "orden social católico" en el que antes que el cumplimiento de la ley era «el compromiso con la fe quien devenía en garante de la estabilidad y perfecta arquitectura de la sociedad civil» ${ }^{24}$.

Clavero, B., op. cit., p. 67.

Idea del Principado... en dedicatoria Al Que Leyere.

IñuRRITEgUI, J. M., op. cit., p. 12.

Clavero, B., op. cit. Passim.

Hespanha, A. M., "La senda amorosa del Derecho. Amor y justicia en el discurso juridico moderno», p. 38; en PETIT, C. (ed.), Pasiones del jurista. Amor, memoria, melancolia. imaginación. Madrid, 1997, pp. 25-56.

24 IÑURRITEGUI, J. M., op. cit., p. 12. 
El príncipe, auténtico pater familias se comportaba, pues, antes como Padre amoroso que como Rey Severo, pero cuando los súbditos obviaban la conciencia, el "padre amoroso», precisamente por serlo, daba paso al "rey-justiciero». Las leyes del rey, es decir, aquellas que permitían al mismo dar a cada quien lo que debía y como debía, la justicia regia, distributiva, entre desiguales, era asimismo fruto y muestra del amor del Rey a los súbditos. Casi un acto de caridad, de amor sin duda; precisamente por amor no podia un «padre» permitir a sus «hijos-súbditos» el quebrantamiento de un orden natural, amoroso, divino; y levantarse contra el príncipe o sus leyes era romper ese orden religiosamente concebido ${ }^{25}$.

Hasta aquí un discurso conocido para la Europa Moderna pero que no parecía ser necesariamente excluyente respecto a otros. El vínculo amoroso entre rey y súbditos se aceptaba también en otras monarquías europeas, pero no era el único ${ }^{26}$. Existía también entre rey y reino una relación de otro tipo marcada por la existencia de un Derecho territorial, reflejo de un entramado comunitario tradicional, que se entendía esencia del territorio mismo. Resultaba de este modo, que entre rey y reino mediaba además de un vínculo amoroso uno jurídico, necesario para que la coexistencia de tal Derecho territorial con la autoridad suprema del territorio, el rey, pudiera verificarse sin entrar en contradicción. La adecuación de ambas realidades pasaba por el entendimiento o la aceptación de un mutuo respeto $y$, aún antes, por el previo reconocimiento de su existencia. Que tal reconocimiento se daba lo demuestra no sólo la efectiva autoridad de un monarca sobre un territorio ${ }^{27}$ sino, más específicamente, la existencia y funcionamiento de una serie de instituciones encargadas de velar por el mantenimiento de tal Derecho territorial.

La Monarquía Hispana tampoco era ajena a la situación que acabamos de describir. Es más, su carácter compuesto de varios reinos que sólo tenían en común un mismo rey, parecía exigir necesariamente tal tipo de situación. $Y$ en buena medida así era, o lo era al menos para el caso que ahora

25 De hasta qué punto el recurso a la justicia fue más una imagen que una realidad nos ocuparemos más adelante.

26 Pero como ha indicado A. M. Hespanha tampoco debemos pensar que dicho vínculo se limitase al ámbito de la retórica; antes al contrario, ya Santo Tomás o Aristóteles lo habían considerado aspecto clave en la política reseñando como tarea esencial del político la creación de tales vínculos afectivos. La amistad, como forma del amor propio de los hombres y que siempre conlleva correspondencia, era el término que mejor definia la relación rey-súbditos siendo, al tiempo, el eje en torno al cual debian estructurarse las relaciones familiares. No podia gobernar un rey su «casa", su reino, a sus súbditos, si no era con amor, con amistad. Quedaba así esta última inmersa, por extraño que se nos antoje, en la política. HespanHA, A. M., op. cit., pp. 48-49.

${ }_{27}$ Es decir, de un espacio para el que se reconoce un derecho territorial. 
nos interesa, el de Cataluña. Las Cortes y otras instituciones como el Justicia Mayor para el reino de Aragón habían nacido para asegurar la observancia del Derecho territorial. La Diputación en Cataluña era una muestra más de lo mismo, de ahí que en la medida en que los rebeldes catalanes justificaran los hechos de 1640 como respuesta a la vulneración de sus fueros y privilegios, la Diputación se encontrase a la cabeza de su bando.

No pretendemos hacer aquí un análisis sobre si la política de Olivares verdaderamente atentaba contra la constitución de libertades catalana o no. Intentamos hablar de los discursos aplicados ante tal situación por parte de la Monarquía y, más concretamente, del empleado por uno de sus polemistas, Pellicer. Lo cierto es que se hubiesen vulnerado o no las libertades catalanas, existía entre Felipe IV y el Principado el vínculo jurídico al que antes nos referíamos. Sin embargo, tanto en su ldea del Principado de Cataluña como en La Astrea Safica, Pellicer parece atender sólo a la ruptura por parte de los súbditos del Principado del vínculo amoroso con su rey. ¿Cómo podía un aragonés pasar por alto el problema que se planteaba en términos de libertades constitucionales? ¿No habría sido lógico responder a una revuelta planteada, teóricamente, por la vulneración de dichas libertades con argumentos que demostrasen que tal vulneración no se había producido?

Desde luego, no es que Pellicer no mencionase el problema de los Fueros; lo hacía, pero la clave estaba en la forma de hacerlo. No se trataba de justificar la política interior de la Monarquía con ánimo de hacer ver que no se habían contravenido las libertades de los catalanes; no se trataba pues de demostrar que no se había faltado al vínculo jurídico. De lo que se trataba era de anularlo, de negar su existencia, de mostrar que la base para tal vínculo había sido la fábula. Y desaparecido éste, la explicación de la revuelta catalana no podía ser más fácil: súbditos rebeldes, "hijos difíciles", vasallos que con demasiada facilidad faltaban a su conciencia. Siempre lo habían sido, su historia así lo demostraba. Esa era la esencia aparente de la ldea del Principado de Cataluña, una demostración de que "los Passados siglos...no contienen otra Memoria, sino es levantamientos, i Desobediencias de Catalanes contra sus Reyes" "28. El fin de hacer memoria de dichas desobediencias también parecía claro: «...Deseo mostrarles lo feo de sus enfermedades pasadas, para que mirandose en ellas, no acaben de enconar esta postrera recaida, i que hallando la senda del Reparo, huyan la del Precipicio... " 29.

\footnotetext{
28 Idea del Principado... en dedicatoria Al Que Leyere.

29 Ibidem. Libro I, p. 4
} 
Hemos dicho "esencia aparente" y no es que no buscase el autor las propiedades moralizantes de la Historia (de hecho, como veremos, ese era el fin último de la misma), pero para que el problema se entendiese como asunto de conciencia (y por tanto fuese necesario buscar una solución en términos morales) había que limitarlo precisamente a ese ámbito, el de la conciencia. El conflicto por los fueros no podía existir, los fueros mismos no tenían que existir o si lo hacian debian carecer de cualquier valor jurídico-político. Era esa la clave de la obra, a...aqui, se les destexe, todo el Humo de los Fundamentos Fantasticos con que se pretenden hacer Espaldas, a su Temeridad..." ${ }^{30}$ pues "...los Catalanes... han llegado a creer, desde que se publicaron mal entendidos i peor interpretados estos Privilegios, que no fueron vasallos conquistados, sino entregados libremente..." ${ }^{31}$. Pellicer daba así la vuelta de tuerca definitiva. Los catalanes eran vasallos conquistados y, por tanto, las libertades en que se escudaban no habían resultado de una relación contractual con el rey sino, todo lo más, de una concesión graciosa de este último y sólo de su voluntad dependía mantenerlos. No cabía obligación, al menos por parte del monarca, pero sí por parte de los súbditos pues la gracia del rey, su amor, se les había hecho patente por medio de tales privilegios, y ya sabemos que este amor generaba una deuda de afecto inextinguible. Justificar los hechos de 1640 empleando los privilegios y fueros catalanes no sólo carecía de sentido, sino que era una aberración.

$Y$ para que no pudiera dudarse, a las afirmaciones que acabamos de ver hacía seguir Pellicer el análisis detallado de los tres Privilegios ${ }^{32}$ que los sublevados catalanes habían convertido en su bandera. A su servicio, todos los instrumentos de la exégesis humanista: las incorrecciones lingüísticas, los errores geográficos... demostraban la falsedad de tales privilegios. Quedaba así el campo libre para aplicar el discurso amoroso que hemos visto. Campo libre para aplicar un discurso de matriz claramente castellana. Sin duda, la intención que se escondía tras ello era cualquier cosa menos inocente ${ }^{33}$.

30 Lidem en dedicatoria Al Que Leyere.

31 Ibidem. Libro I., p. 17. Aún es más claro Pellicer en la dedicatoria de la obra cuando, sin ningún tipo de reparos, habla de "la Certidumbre de que en su principio fueron los Catalanes, Vassallos Conquistados, i no Pactados ni entregados voluntariamente como pretende la Proclamacion...".

32 "...los dos del Emperador Ludovico Pio, que se hallaron en el Tabulario o Archivo de la Iglesia de Narbona, i se estamparon con algunos escritores de los anales de Francia que salieron a la luz de la libreria de Pedro Piteo... El tercero imprimio Fray Francisco Diago del Orden de Predicadores...diziendo averse hallado bien, en los Archivos de la Catedral de aquella ciudad, i ser del Emperador Carlos el Calvo en abono de los otros dos...". Ibid., p. 16.

33 La refutación de los privilegios se enmarcaba en la postura general del que podriamos denominar "bando olivarista" en relación a la polémica, pues según parece a fines del siglo XVI 
¿Por qué de matriz de castellana? Ya antes hemos indicado que el vínculo amoroso entre rey y súbditos era reconocible de forma general en la cultura política de la Europa Moderna y, en tal sentido, el lenguaje en torno a él generado no debía ser más castellano que inglés, francés... sin embargo, también hemos señalado que dicho vínculo no excluía la existencia de otros igualmente importantes. Es aquí donde parece situarse la excepción castellana, pues en Castilla el único vínculo reconocible entre rey y reino era el concebido en términos de amor. La reacción nobiliaria a la crisis del siglo XIV había acabado con el Derecho territorial castellano, y no existiendo éste no tenía por qué existir ninguna fórmula de relación entre el territorio (ya que no habia) y la suprema autoridad sobre el mismo, el rey. Por lo mismo, tampoco eran necesarias instituciones como la Diputación, es decir, instituciones que representasen a un territorio inexistente ${ }^{34}$.

En Castilla pues, como en ningún otro reino, la relación que cabía con el soberano era económica y no política. No había un entramado comunitario, un ámbito de cosas comunes sobre el que tratar, siendo la única negociación viable la de carácter personal, claro está, en la corte. El rey era padre económico respecto a aquellos con los que no tenía una relación política. Pero una relación económica se fundamentaba en amor, en un amor entre desiguales a modo del existente entre Dios y los hombres, en un amor, por tanto, expresión de un orden religioso y, como hemos visto, teológicamente definido. El espacio de lo político era el espacio de lo religioso en Castilla. La política era religión y la religión, política; la esencia misma de la Monarquía Católica tenía en Castilla su expresión más depurada. Detrás de ello se encontraba toda una visión del mundo, religiosa y católica, una visión que, como trataremos de explicar, daba su ser a la propia Monarquia.

En cuanto a las nada inocentes razones de Pellicer para aplicar un discurso castellano a Cataluña, parecen bastante evidentes. Si en Castilla

\footnotetext{
surgió en Cataluña una nueva concepción de sus orígenes históricos, cuya formulación última quedaría expresada en la condición de "nunca conquistado" del Principado y que alcanzaría su mayor difusión en los años cuarenta del siglo xvII. Frente a dicha formulación (vinculada a los origenes carolingios de Cataluña) serían varios los autores que negarian la condición de vasallos pactados y no conquistados a los catalanes (como Francisco de Rioja o Juan Adam de ia Parra), siendo así la argumentación empleada por Pellicer en la ldea del Principado de Cataluña manifestación de un lugar común para la mayor parte de polemistas por entonces al servicio de la Monarquía. Para mayor profundización en estos aspectos Vid. VILLANUEVA, J. «Francisco Calça y el mito de la libertad originaria de Cataluña», Revista de Historia Jerónimo Zurita, 69-70, 1994.

${ }^{34}$ Al fin y al cabo, los Procuradores de las Cortes castellanas sólo representaban a las quince ciudades que eran patrimonio cameral del rey, no al conjunto de ciudades del reino. Sobre este particular Vid. Fernández Al.baladejo, P. y Pardos Martínez, J. A., "Castilla, territorio sin Cortes (sigios XV-XVII)", Revista de las Cortes Generales. 15 (1988), pp. 113-208.
} 
no podía existir una relación contractual entre rey y reino porque la inexistencia de una constitución de libertades habia hecho innecesaria la negociación entre ambos, tampoco podía haber instituciones del reino que, de algún modo, limitasen el poder del monarca. El juego de dominios como recordaría Diego Felipe de Albornoz no quedaba establecido entre rey y reino ${ }^{35}$, ya que no era del reino (entendido como territorio y, por tanto, como posesor del dominio directo) ni de Dios a través del reino, de quien el soberano recibía el dominio útil sobre el mismo. El dominio directo sólo podía corresponder a Dios ${ }^{36}$ de quien recibía el soberano el dominio útil; sólo Dios, entonces, era el límite al poder del rey, al menos teóricamente. Si Pellicer negaba la vigencia o validez de los privilegios del Principado de Cataluña, negaba la base de su Derecho territorial, de su constitución de libertades y, con ello, la posibilidad de una relación contractual rey-reino en la que el segundo fuese señor del dominio directo. La posibilidad de una autoridad regia tan absoluta como la que se daba en Castilla era lo que Pellicer estaba brindando y justificando para el caso catalán, algo cuando menos sugerente para un momento de crisis y búsqueda de reformación interior.

La sublevación catalana había quedado explicada en términos de conciencia y en esos mismos términos había que solucionarla. Pero la conciencia de los catalanes no sólo estaba en peligro por su desobediencia; otro factor hacía que los hechos de 1640 se vieran con especial temor, con temor confesional: la presencia francesa. En septiembre de 1640 la Diputación, ante la inminencia de una respuesta armada de la Monarquía, había solicitado formalmente ayuda militar francesa y unos pocos meses más tarde, en enero de 1641, Luis Xlil se convertía en el nuevo Conde de Barcelona. Cataluña que desde 1635 había sido el tapón frente a Francia se convertía ahora en aliado francés, en aliado de los herejes del xVII, los politiques 0 ateistas.

La francofobia de Pellicer es sobradamente conocida ${ }^{37}$ y no era éste el momento de disimularla. En el Argumento de La Astrea Safica, fechado a

35 Diego Felipe de Albornoz. Cartilla politica Christiana. Madrid, 1666, fol. 1 (dorso).

36 "No mantiene las Coronas la razon de estado, sino Dios, que como dueño universal de los Reynos los muda, altera, o conserva, y assi es necessario reverenciarle, como a Supremo Señor del dominio directo". Ibid.

37 A este respecto nada más ilustrativo que su participación en la polémica de 1635 estudiada ampliamente por José $M^{\text {a }}$ Jover (op. cit.). en esta obra ya clásica, Pellicer junto con otros activos polemistas del momento es objeto de un estudio pormenorizado que le sitúa como miembro de una ge neración de autores (Saavedra Fajardo, Guillén de la Carrera, Céspedes y Meneses...) que compartirian una muy similar visión del mundo y cuyo discurso sobre 1635 responde a unos supuestos de fondo que nos informan ya sobre su futuro posicionamiento ante los hechos catalanes de 1640 . 
9 de noviembre de 1640, desde luego no lo hacia, dando al tiempo la clave del que hemos denominado "temor confesional»: "...la Ambicion de los Ministros del Rey Christianissimo, con animo de deshazer el poder, $i$ el Imperio de España, i de Austria: dando ocasion para que...los Infieles, los Herejes. y demas enemigos de la Iglesia Apostolica Romana, echen mas que profundissimas raizes en sus torpes Setas; i se vaya haziendo su poderio mas incontrastable. Tal es la sed ambiciosa de Francia en querer ensanchar su Reyno, con pretension humana, i esta Razon Politica, que Ilaman Conveniencia de Estado, que tan de proposito se encuentra con el Evangelio..." ${ }^{38}$.

Razón Católica frente a Razón Política; el problema era de esencias. La razón política o de estado no era otra que la de aquellos que se mostraban dispuestos a anteponer la salvación y bien de éste al mantenimiento de la religión, es decir, aquellos dispuestos a aceptar soluciones políticas para el conflicto confesional que vivía Europa, en virtud de un bien mayor para el Estado ${ }^{39}$. Francia ya lo había hecho en el siglo anterior y continuaba haciéndolo en el xVII. Frente a ella tocaba a la Monarquía Hispánica afirmar la ortodoxia de la catolicidad, pues la razón de estado era, como hemos visto, contraria al Evangelio; se trataba de un error ya que no era a la política, asi entendida como herejía, sino a la religión a quien competía la conservación de las monarquías ${ }^{40}$. Si los catalanes, en el fondo súbditos del monarca hispano, abrazaban tal error, varias eran las cuestiones que debería sopesar este último. Por un lado y en relación con lo que acabamos de afirmar, que la postura catalana, en última instancia, ponía en peligro la propia conservación de la Monarquía Católica. Su fundamento no era otro que la religión y no sólo en el sentido más general de preeminencia de la teologia sobre la política, sino en el sentido más específicamente casteliano que hemos visto de ausencia de esta última o su reducción a Teología moral ${ }^{41}$ y, en esa medida, los catalanes estaban

38 Astrea Safica, pp. 29-30.

39 Sobre este planteamiento y sus consecuencias: VIEJO YHARRASSARRY, J., “Razón de Estado Católica y Monarquía Hispánica" en Revista de Estudios Políticos (Nueva Época), núm. 104, abril-junio 1999.

${ }_{40}$ Sobre esta constante no sólo Pellicer; también en la citada Cartilla de Felipe de Albornoz: "No mantiene las coronas la razon de estado, sino Dios..." (fol. 1, dorso), o el propio Salazar en su Política Española de 1619: “El fundamento...en que estriba esta gran monarquia y las columnas sobre que se ha sustentado, y con el favor divino se ha de sustentar por muchos siglos, no son las reglas y documentos del impio Maquiavelo que el ateísmo llama razón de Estado... sino la religión, el sacrificio y culto divino y el celo de la honra y servicio de Dios..." (Proposición tercera, I, pp. 53-54. Tomamos la cita de la edición publicada por el Centro de Estudios Políticos y Constitucionales en 1997).

41 Viejo YhaRrassarRy, J., op. cit., p. 236. 
atacando al fundamento de la Monarquía ${ }^{42}$. Además, y esta era otra de las cuestiones a tener en cuenta, cabía la posibilidad de "contagio" del error a otros reinos, especialmente si consideramos la convulsa situación de la década de los cuarenta. Por tanto, en bien de la Monarquia era necesario sacar a los catalanes de su error; más aún, era obligación del rey católico hacerlo, pues regresar a la verdad al hereje no dejaba de ser un acto de caridad, de amor, lo que lógicamente debía esperarse de un buen padre, y el monarca hispano lo era.

Todas estas razones explican el que la guerra con Cataluña pudiera entenderse en la época como una guerra de religión, es decir, contra quienes compartiendo los errores de los herejes habian faltado a su conciencia. ¿Y qué sucedía con Portugal? Ya hemos dicho que en su Sucession de los Reynos de Portugal i El Algarve aparentemente el tratamiento del problema dado por Pellicer podría parecer distinto. Sin embargo, nada más lejos de la realidad pues, si bien es cierto que el corpus de la obra se centra fundamentalmente en demostrar la justicia de los títulos con que Felipe II se convirtió en 1580 en rey de Portugal, ya desde su título se nos pone sobre una pista similar a la catalana, ya que Portugal, en justicia, desde su origen habría formado parte de la Corona de Castilla de la que habría salido primero como dote pero, definitivamente, para ser tiranizado ${ }^{43}$. Así, el auténtico señor natural de Portugal resultaba ser, como en Cataluña, el monarca hispano (Don Juan de Avís no podía ser reconocido como rey en derecho por ser bastardo ${ }^{44}$ ); además, los derechos de Sangre

42 Curiosamente, de forma paralela al episodio de 1640 como amenaza para la conservación de la Monarquía surgió en el entorno catalán una interpretación de los hechos que venía a entenderlos como muestra del peligro que para dicha conservación constituía el discurso político trazado por Olivares, y presentando por el contrario al Principado como auténtico garante de la preservación de la Monarquia. Para esta idea cfr. Fernández Albaladejo, P. «España desde España", en Belenguer, E., Fernández Albaladejo, P. y Arrieta, J. (eds.). Idea de España. Valencia, 1998. Es más, entre las treinta y siete razones que constituian la propia Proclamacion catolica a la Magestad Piadosa de Felipe el Grande Rey de las Españas, y Emperador de las Indias Nuestro Señor. Los Conselleres, y Consejo de Ciento de la Ciudad de Barcelona (1640), a la que Pellicer daba contestación con su Idea del Principado de Cataluña, en el punto catorce se afirmaba lo siguiente: "Cataluña es seguridad, y firmeza della Corona de sus Principes. Descrivese su fortaleza. No importa tanto a V. Magestad este Principado por lo precioso, y antiguo, quanto por lo fuerte, $y$ seguro; y pretender su ruina, es desmantelar la Monarquia de $V$. Magestad el lienço mas fuerte de sus muros" (p. 145).

43 Así, Pellicer titula la obra Sucession de los Reynos de Portugal i El Algarve, feudos antiguos de la Corona de Castilla: Dados en dote a Doña Teresa i Don Enrique de Borgoña, Tiranizados la primera vez por Don luan Maestre de Avis; Conmovidos luego por Don Antonio Prior de Ocrato, Incorporados despues en la Monarchia de España, Por Derecho de Sangre, i otros Ocho diversos Titulos, que justificaron la Union, en la Real Persona del Rey Don Felipe Segundo el Prudente...".

${ }_{44}$ Dirá Pellicer en el Argumento de la obra a que nos referimos: "Es mi proposito manifestar al mundo una compilacion sucinta de la sucession de los Reynos de Portugal i el Algarve. Quando 
con que Felipe II había accedido al trono portugués despejaban cualquier duda al respecto, pues «no era Rey Estrangero el que los havia de heredar, sino muy Natural suyo" "45. Ningún valor tenía asi la argumentación de los partidarios del Duque de Braganza de que lo que se intentaba en 1640 era una Restauración. Si la causa lusa no era legítima, como tampoco lo era la catalana, lo que se tenía era unos súbditos que, una vez más se negaban a atender a su conciencia, que habían faltado a la deuda de amor con su soberano y, por tanto, que habian roto con el orden natural religiosamente concebido al que ya nos hemos referido antes: «...conspiro [el Duque de Braganza] con una grande Lista de Conjurados, entre Prelados, Titulos $i$ Señores de aquel Reyno, tan del todo beneficiados, y enriquecidos por el Rey nuestro Señor, que solo esta Ingratitud pudo igualar aquellos Favores. Olvidando tantas Obligaciones, pospuesto el Temor de Dios en primer lugar, i luego atropellando por la Fidelidad a su Verdadero Señor, sin acordarse de la Ley de Cristiano, $i$ del Respeto de Cavallero..." ${ }^{46}$.

El mismo discurso, pues, para Portugal que para Cataluña; tan es asi, que también la portuguesa pudo entenderse como guerra de religión, no sólo por la posibilidad del recurso al francés por parte de unos portugueses rebeldes que veían cómo Francia apoyaba a otros rebeldes de la monarquía, los catalanes ${ }^{47}$, sino porque, al fin y al cabo, el asunto era de conciencia y la conciencia remitía a religión. No podía ser más claro Pellicer al comienzo de su Sucession cuando decía: “...la Enorme Resolucion i Tirana Inobediencia de Don luan, Duque de Bragança...imitando la Felonia de Federico de Baviera Conde Elector Palatino...procuro despedaçando la Corona, lograr el Fruto de ayudar a la tan solicitada Caida de la Augustissima Casa, como si huviera nacido Sueco o Herege, i no Español i Catolico...beviendo la Politica torpe de Mahoma, Lutero, Calvino i Machiavelo..." ${ }^{48}$.

Un mismo discurso y por lo tanto una única forma de entender el mundo en clave católica; la confesión católica constituía por encima de cualquiera otra cosa la esencia de la Monarquía, era pues el eje de coordenadas en el que enmarcar todo, política, derecho, cultura... el único contexto posible

\footnotetext{
salieron como feudos, de la Corona de Castilla; Con que havian de ser debueltos a ella como Semovientes suyos? En que forma los usurpò con Don luan Maestre de Avis, a Don luan Primero de Castilla, quando los portugueses por tener Rey de por Si no repararon en que fuesse bastardo?

45 Ibidem, p. 10.

$46 \quad$ Ibidem, p. 6.

47 De hecho, la ayuda francesa acabaría materializándose en el verano de 1641 después de que Portugal firmase con Holanda en junio del mismo año una tregua por diez años que permitió a Francia suministrar tal ayuda con garantias de no enemistarse con sus aliados holandeses.

48 Sucession de los Reynos..., pp. 5-6.
} 
en el que entender, analizar y dar solución a los avatares del momento presente. No hacerlo así sería imposible, pues exigiría la negación de la Monarquía Católica misma.

Había quedado claro que ni catalanes ni portugueses estaban dispuestos a dar marcha atrás en sus errores y atender a su conciencia. El siguiente paso hemos visto que quedaba claro, la justicia del rey. Sin embargo, el recurso a ésta última resultaba ser más retórico que real respondiendo fundamentalmente al topos del rey-justiciero característico en la Europa moderna.

Ligada a la caracterización amorosa del poder político se encontraba la imagen del rey como dispensador de justicia pues, si la posibilidad del «castigo" se vinculaba a tal imagen, el recurso al perdón, a la clemencia, se vinculaba a otra de sus facetas, la de padre. Como indica M. Hespanha «esta dialéctica del temor y la clemencia constituía al rey simultáneamente en señor de la Justicia y mediador de la Gracia" "49. Y precisamente de la mano de la imagen del rey como señor de la justicia fue su caracterización como Astrea.

"En su siglo Ovidio, escrivio que ASTREA se huyô al Cielo, por no hallar acogida en la Tierra. En el nuestro, bolvio a descender a España fiada en la entereça, i justicia del Gran Monarca que nos govierna. Assi, por ser devidos de justicia todos los Elogios a su Magestad Catolica, llamè, e intitulè ASTREA a este Panegirico, y SAFICA; por los versos de que consta» ${ }^{50}$. Eso era la Astrea Safica, una caracterización de Felipe IV como rey justiciero, como Astrea, encarnación de la justicia ${ }^{51}$.

Según la narración de Ovidio del primer libro de sus Metamorfosis a la que alude Pellicer, durante una mítica edad de oro, los hombres habrían vivido bajo el gobierno de Saturno reinando entre ellos las más perfectas paz, armonía y justicia; esta situación idílica se habría ido deteriorando con el tiempo (y especialmente desde la caída de Saturno) dando paso a otras tres edades (de plata, de bronce y de los héroes) en que la maldad de los hombres habría ido abriéndose camino. Así, al mismo tiempo que

\footnotetext{
49 Hespanha, A. M., op. cit., p. 40.

50 Astrea Safica..., pp. 25-26.

51 Este tipo de figuraciones no era en absoluto ajenas al imaginario asociado a los monarcas de la Casa de Austria, pues tal y como ha demostrado M. TANNER en su The last descendant of Aeneas. The Hapsburgs and the Mythic Image of the Emperor (New Haven, 1992), prácticamente desde sus orígenes, y dadas las connotaciones de dominio universal, piadoso y obediente a la elección divina, asociadas a la imagen mítica de Eneas, los Austrias auspiciaron la creación de genealogías mí ticas que los presentaban como descendientes del heroe troyano. En este sentido, el empleo del mito de Astrea asociado a Felipe IV no era más que otra muestra de este tipo de recursos.
} 
se descubrían los metales, la guerra y las armas se adueñaban de la vida en la tierra y con ellas se iba relegando la justicia encarnada en la inmortal Astrea, quien tras refugiarse cada vez en lugares más altos, acabaría ascendiendo al firmamento para formar allí la constelación de Virgo.

El mito clásico (que el propio Ovidio recogía siguiendo la tradición de Hesiodo en Los trabajos y los días y de Arato en los Phaenomena) aparentemente desprovisto de mayor trascendencia, acabaría por convertirse en uno de los símbolos recurrentes dentro de la retórica política de la Europa moderna. Pellicer fue sólo uno de los muchos autores que recurrieron a él para hacer un panegírico de su soberano pues, con el recurso al mito de Astrea no sólo reforzaba la imagen del rey-justiciero por analogía del mismo con la diosa clásica de la justicia, sino que yendo aún más lejos, lograba un encaje perfecto de la imagen de Felipe IV con la esencia de la propia Monarquía Hispánica: un proyecto de dominio universal religiosamente entendido.

Para poder comprender las implicaciones religiosas y de dominio universal vinculadas al mito de Astrea, debemos remontarnos hasta Virgilio, ya que fue la elaboración que del mito de la edad de oro hizo el poeta romano en la Cuarta Égloga y en la Eneida, la que permitió posteriormente desarrollar una doble interpretación imperial y mesiánica del mismo ${ }^{52}$. Así, en la primera de estas obras, Virgilio incluyó una profecía sobre la vuelta de la edad idílica de Virgo y Saturno a través de un niño que habría de nacer para gobernar sobre toda la humanidad en una nueva y pacífica era. Dicha profecía se retomaba en el texto de la Eneida para afirmar que el retorno a la edad de Saturno habría de producirse bajo el gobierno de Augusto; la razón de tal coincidencia guardaba relación con el logro de la Pax romana bajo dicho emperador, paz que Virgilio identificó fácilmente con el regreso de la justicia descrito en el mito de Astrea. De este modo, se unía definitivamente la idea de un poder imperial a la imagen de Astrea (la justicia) y con ella a la creencia en el regreso de una edad dorada. Esta asociación fue asimismo reforzada por otros autores como Manilio, quien se encargaría de enriquecer esta versión de Astrea con aspectos morales vinculados a su piedad, llegando a hacer de la diosa objeto de culto estatal en Roma como representante de la virtud y la paz ${ }^{53}$.

52 Sobre las interpretaciones del mito de Astrea por otros autores clásicos y del propio Virgilio y sus repercusiones en siglos posteriores Vid. DE AAMAS, F., "Astraea Returns: Genesis" en The return of Astraea: an astral imperial myth in Calderon. Kentucky, 1986. De forma más concreta sobre las interpretaciones imperiales y mesianicas del mito Vid. YATES, F. A., Astraea: the imperial theme in the sixteenth century. Londres, 1985, pp. 33-38.

53 Las razones de tal enriquecimiento guardarian relación con interpretaciones astrológicas sobre la constelación de Virgo y los nacidos bajo su signo. Vid. YaTES, F. A., op. cit., p. 34. 
En cuanto a la faceta mesiánica del mito narrado por Virgilio, no tardaría en conocer una versión cristianizada que el emperador Constantino haría pública y San Agustín y Lactancio se encargarían de elaborar seriamente. La virgen (Virgo) que habría de regresar a la tierra no sería otra que la Virgen María y el niño llamado a redimir a los hombres, sería Cristo, su hijo. Conseguía así el primer emperador cristiano unir la costumbre imperial de culto a Astrea con la tradición cristiana. En este sentido, como indica De Armas, la convivencia de las facetas pagana y cristiana del mito no supuso un problema, ya que a cada una de ellas se le reservaban distintas funciones; mientras la primera permitía el elogio de cada nuevo soberano como artífice del deseado retorno de la justicia (algo que, hemos visto, también haría Pellicer), la segunda permitía a los cristianos ver en el mito de Astrea el anuncio del nacimiento y redención de la humanidad por Cristo, haciendo asimilables la Pax romana de Augusto (bajo la que se había producido la Natividad), en tanto que nueva edad dorada, con una "paz cristiana» universal a partir del advenimiento del Mesías ${ }^{54}$.

Esta doble interpretación mesiánica y secular del mito de Astrea sobrevivió a lo largo de la Edad Media, durante la que iría reforzando su dimensión política. Así, uniendo la faceta imperial del mito a la interpretación religiosa del mismo ( $y$ a la luz de la coronación de Carlomagno como Emperador Augusto por el Papa, que lo convertía en brazo armado de la Iglesia) cristalizaba en la conciencia de Occidente la idea de que el retorno de la justicia estaba ligado a la paz universal bajo un sólo gobernante, bajo un Dominus Mundi que habría de ser el primero entre los cristianos. La recuperación del Derecho y Filosofía clásicos contribuirían firmemente a ello.

De la mano de Dante (que en su Monarchia formula ya con precisión la teoría del Dominus Mundi) entre otros autores, el mito de Astrea pasaria a la modernidad, siendo uno de los puntos de interés común de intelectuales ya plenamente renacentistas interesados en la obra de clásicos como Virgilio. El mito, con tintes imperiales y cristianos, continuó manteniendo su popularidad a lo largo de los siglos XVI y XVII, tintes que no pasarían por alto para las monarquías de la época y, claro está, tampoco para la Hispánica. Enrique II y Carlos IX en Francia, o Isabel y Carlos II en Inglaterra fueron algunos de los monarcas identificados por sus panegiristas con Astrea, la edad de oro, el retorno de la justicia, el poder llamado a la universalidad... ${ }^{55}$. Esta tradición también encontró su lugar entre los monarcas

54 De Armas, F., op. cit., p. 14.

55 A este respecto no podemos dejar de señalar el estudio de F. A. YATES (op. cit.) sobre la caracterización de Isabel I como Astrea, que se incluye entre otros ensayos en la obra ya citada. 
españoles, siendo el de Astrea uno de los temas recurrentes en la literatura de nuestro Siglo de Oro ${ }^{56}$.

Desde los Reyes Católicos a Felipe IV el mito de Astrea se empleó con fines de propaganda política, pero sería a partir de su uso en el Orlando furioso de Ariosto (1516) cuando la significación imperial y religiosa del mito alcanzaría su grado de expresión más depurada. En él se profetizaba que, fruto de la unión de las casas de Austria y Aragón, nacería un niño a través de quien Astrea-Justicia y el resto de las virtudes serían restauradas en la Tierra, estableciendo sobre el mundo una monarquía universal como sucesor de Augusto ${ }^{57}$. El mito de Astrea así perfilado, encajaba perfectamente para un Carlos $V$ (que era de quien se hablaba) al que todo parecía señalar como Dominus Mundi. Su posesión del título imperial unida a los dominios de la corona hispana hacian de Carlos $\mathrm{V}$ el candidato ideal a tal postura; más aún, desde el Saco de Roma el simbolismo imperial asociado a Carlos $V$ no sólo parecía vincularse a su dominio sobre buena parte de un mundo cuyas dimensiones eran las mayores hasta entonces conocidas, sino también a la posibilidad de lograr la unidad espiritual de Europa poniendo fin a los desmanes de la Iglesia ${ }^{58}$.

Si bien es cierto que Carlos $V$ no lograría dar una solución de concordia al conflicto confesional planteado en Europa en el siglo XVI y que los siguientes Austrias hispanos no recibieron el título de Emperadores, también lo es que la dimensión religiosa y de dominio universal que con Carlos $V$ había alcanzado el mito de Astrea resultó ser un molde perfecto en el que encajar la imagen que los monarcas católicos quisieron dar de sí mismos y de la propia Monarquía. En su nombre, Monarquia Católica, se encerraba la esencia de un proyecto cuya cabeza visible no podía ser mejor caracterizada que como el retorno de la justicia, pero un retorno llamado a ser universal puesto que tendría por misión velar por el logro de la salvación de la humanidad.

¿Por qué los planteamientos universalistas vinculados al mito de Astrea encajaban tan bien con la figura del monarca católico? Una vez más hablamos de una cuestión de esencias, de aquello que se pensaba debía ser la Monarquía Católica; Pellicer daba perfecta cuenta de ello:

"Señor/ El Cielo os ha hecho el mas alto Monarca/ que el Mundo gozó desde el siglo del Arca./ Callen Asirios, Persas, y Griegos, / y queden de

56 Sobre el uso del mito de Astrea por autores como Fray Luis de León, Cervantes, Lope de Vega, Góngora, Quevedo...Vid. "Astraea in the Spanish Golden Age» en DE ARMAS, F., op. cit.

YATES, F. A., "Charles $V$ and the idea of Empire" en Astraea..., op. cit.

Es Ibidem, p. 27 
Roma, los Cesares ciegos./ Pues vuestro Imperio, Mayor que el de todos,/ forman Invicto, Españoles, y Godos" 59.

Aparentemente se trataba sólo de un elogio, y lo era, pero cada una de las palabras en él empleadas había sido cuidadosamente escogida, ya que definían con notable precisión lo que se entendía por Monarquía Católica. Felipe IV era "el mas alto Monarca", no rey o soberano, "Monarca”, y mucho se cuidaba Pellicer de no aplicar tal calificativo a ningún rey extranjero, pues sólo en los monarcas católicos concurrían las condiciones necesarias para serlo. Monarca era el más grande entre los reyes; así lo afirmaban autores como Salazar, que en su Política Española entendía "por monarca el mayor de los reyes, y por monarquía el casi total imperio y señorío del mundo" ${ }^{60}$, condiciones que, aseguraba, cumplia la Monarquía Hispánica. Se presentaba de este modo una Monarquía que lo era por ser el mayor poder entonces conocido como anteriormente habian sido asirios, persas, griegos y romanos ${ }^{61}$. Tal poder lo certificaban tanto su extensión, que incluso superaba la del mundo conocido y dominado por los romanos, como la justicia con que se había convertido en titular de los reinos que la componian ${ }^{62}$. Pellicer sólo era un autor más en esgrimir tales argumentos: "De entrambas Castillas, Navarra, y Leon/ con la de Portugal, y la de Aragon./ Ennobleciendo la Austriaca Alcuña,/ Sicilia, Valencia, y tambien Cataluña./ Sin otras que os hazen, Señor soberano,/ treynta y dos vezes Mayor que el romano", y antes, "...en tan amplios Reynos, i tan estendidas Provincias como le obedecen, [al monarca católico] no se hallarà un palmo de Tierra, que no sea legitimamente señoreado por herencia, i sucession de padre a Hijo...» ${ }^{63}$.

$59 \quad$ Astrea Safica..., p. 39.

60 Op. cit., p. 24.

61 La alusión de Pellicer a estos pueblos tenia su razón en la tradicional creencia en una de las visiones del profeta Daniel recogidas en la Biblia, según la cual habrian de sucederse cuatro monarquias o imperios de alcance universal tras los que, finalmente, llegaría una quinta monarquía del pueblo de Dios (identificado con la cristiandad católica) que sería la última. Para una descripción pormenorizada de esta tradición y su vinculación a la Monarquía Hispánica Vid. SALAZAR, J., op. cit., pp. 119-231.

62 Este tipo de argumentos encaminados a demostrar la superioridad de un poder sobre otros no eran desconocidos para la tradición hispana. Ya en el siglo xV. Alfonso Garcia de Santamaría, con ocasión del Concilio de Constanza, se había encargado de demostrar la superioridad de Castilla frente a Inglaterra empleando, entre otras razones similares, la superioridad castellana en antigüedad y tamaño de nación (razón esta última que se hacia remitir hasta Aristóteles). Sobre esta cuestión Vid. TATE, R. Ensayos sobre la historiografía peninsular del siglo xv. Madrid, 1970.

63 Astrea Safica..., pp. 39 y 33 . Y aún más preciso sobre esta misma idea al arremeter contra Francia: “...no repara en el detrimento que padece la Christiandad... i en la opression de la lusticia, a trueco de verse con una Provincia mas, ganada con engaños, $i$ violencias, que son las ultimas razones, i justificacion de los Principes, i Reyes" (p. 30). Quedaba claro. "Principes i Reyes", no monarcas. 
Podía entonces llamarse monarquía a la Católica. Sin embargo, bajo esta aparente cuestión de términos se estaba diciendo mucho más: se identificaba la Monarquía como protagonista de una experiencia histórica singular fruto del designio divino y, en estrecha relación tanto con ese carácter elegido como con la propia definición que acabamos de ver, se justificaba un poder de aspiración universal que, en lo temporal, no reconocía superior alguno.

Por lo que a este último punto se refiere, fue el universalismo (junto con la catolicidad) uno de los pilares que conformaron la identidad de la Monarquía, pilar que podía remontarse de forma ininterrumpida hasta época medieval ${ }^{64}$. La existencia de un poder universal en el ámbito secular, así como en el religioso, no era una idea ajena a la tradición política europea moderna, si bien es cierto que Carlos $V$ sería su último representante en los términos en que se había definido durante la Edad Media. Sin duda, Carlos $V$ también había sido el más grande entre los reyes, un monarca además de emperador; y para los siglos siguientes (en la Monarquía Hispánica) sería la primera de ambas condiciones la llamada a tener mayor trascendencia, pues la calificación de monarca expresaba como ninguna la no sujeción del rey hispano a cualquier otro poder secular.

La tradición ya venía de atrás y se legitimaba en la Reconquista, singular baza empleada para consolidar la "exemptio ab imperii" de los reinos hispanos ${ }^{65}$. Con Carlos $V$ se había producido la más deseable de las conjunciones: el monarca hispano era también el emperador, es decir, a la factualidad de un poder universal que le hacía "emperador de por sí» ${ }^{66}$, se unía la dignidad del título que tradicionalmente en Europa había expresado tal tipo de poder en la esfera temporal. Por ello, cuando el título imperial quedó fuera del alcance de los monarcas hispanos, continuaría siendo posible la vinculación de un poder universal con los mismos. Ser "Monarca de las Españas" era ser "emperador" de las mismas, esto es, ostentar el mayor poder secular conocido, un poder que, en ese terreno, no reconocía ningún tipo de dependencia. No era necesario el título imperial germánico; la universalidad era parte de la esencia, del ser, de la Monarquía misma; estaba en su origen. Nada de raro tenía pues, que Pellicer

64 Sobre este particular y sobre la concepción identitaria de la Monarquía Católica, vid., Fernandez Albaladejo, P.. Fragmentos de Monarquía. Madrid, 1992, pp. 60-184.

6.5 Ibidem, pp. 60 y ss.

66 No olvidemos que el propio Hernán Cortés, a raiz del descubrimiento y conquista del Nuevo Mundo, habia ofrecido a Carlos $V$ la posibilidad de un título imperial de nuevo cuño. A este respecto Vid. "Imperio de por sí: la reformulación del poder universal en la temprana Edad Moderna" en Fefinandez Albaladejo, P., Fragmentos..., op. cit., pp. 168-184. 
al dirigirse a Felipe IV hablase de "Imperio, Mayor que el de todos». La Monarquía lo era con todas sus consecuencias.

Se tenía un edificio político, la Monarquía Hispánica, que en su propia configuración genética se definía como forma de dominio de vocación universal. Pero dicha vocación universal no sólo se anclaba en fundamentos "físicos". Más allá de éstos, en los márgenes de lo "metafísico" se encontraban anclajes, tan o aún más fuertes, para este proyecto.

Según hemos visto, la Monarquía podía, en rigor, denominarse de tal modo; su extensión y justa forma de dominio así lo acreditaban. Pero, ¿por qué precisamente la Monarquía Hispánica? Pellicer, como tantos otros, daba la respuesta: "El Cielo os ha hecho el mas alto Monarca". Estaba claro, si se gozaba del mayor poder secular en la tierra sólo podía ser porque así Dios ("que como dueño universal de los Reynos los muda, altera, ò conserva" ${ }^{67}$ ) lo había querido. Cabía deducir entonces de forma legítima que la Monarquía Hispánica había sido elegida frente al resto por Dios; pero, nuevamente había que preguntarse el por qué de hacer a la Monarquía Hispánica el sujeto de esa elección. Las respuestas eran también unívocas en este caso: era la elegida por ser la primera y mejor cristiana. Así, no sólo los hechos de que bajo sus dominios se conservase como en ninguna otra parte del mundo conocido la religión católica, y de que con su asombrosa expansión hubiese extendido el catolicismo en la mayor de las medidas posibles, avalaban su irrefutable catolicidad. Más aún y como hemos venido viendo, en la propia esencia de la Monarquía radicaba la defensa de dicha religión, pues era lo que daba sentido a su existencia y el principio rector de todos sus actos. La mejor muestra de ello la hemos visto: su razón de estado católica ${ }^{68}$.

Monarquía Católica. Esa y no otra era la denominación más exacta que podía dársele. Era monarquía por su extraordinario poder, y tal poder estaba en sus manos por ser precisamente católica. Pero había más, ya que algún fin tenía que haber en la elección divina. Y asi era; la Monarquía como instrumento divino en la tierra tenía una misión religiosa (que, obviamente repercutiría en lo político), pues de ella dependía garantizar el objetivo último de Dios: la salvación de los hombres. Pero no debemos llamarnos a engaño, tal propósito no implicaba un planteamiento escatológico. La Monarquía Católi-

\footnotetext{
67 Felipe de Albornoz, D., op. cit. Fol. 1 (dorso).

68 La razón de religión era el símbolo más evidente de su superioridad entre los católicos y la causa última que explicaba el especial favor divino que recibía: “...Pero como en su Magestad es primero siempre la Religion del juramento, i la Fe de su Real Palabra, que todos los interesses humanos...Dios le ha dado tantos Reynos, i Señorios, que pueden llenar el espiritu mas levantado..." (Astrea Safica..., p. 31).
} 
ca no debía velar por el mantenimiento en la fe de una comunidad escogida llamada a salvarse al final de los tiempos. Desde la venida de Cristo la Salvación estaba garantizada para todos los hombres y precisamente por ello, porque ya no era necesaria ninguna otra venida del Mesías, existía una institución, la Iglesia, que Cristo habría dejado en la tierra como mediadora de una salvación que no se encontraría fuera del proceso histórico, de ahí que tal institución fuese considerada poder universal. Sin embargo, no podemos pasar por alto que dicho poder universal y religioso se encontraba inserto en un mundo secular y, por tanto, amenazado por todos los peligros del mismo. Era aquí donde entraba en juego la Monarquía Católica, instrumento de Dios en el ámbito temporal de igual modo que la Iglesia lo era en el religioso. Su papel era fundamental; estaba llamada a ser el sostén de esta última y no era ese un aspecto que Pellicer pudiera pasar por alto al elogiar a Felipe IV: «O Grande Rey, Coluna vigilante, / A donde carga de la Iglesia el peso, / Catolico pilar contra el exceso/ Del Turco, del Gentil, y el Protestante./ Hercules de la Fè siempre triunfante,/ Que el Gerion de Setas tiene preso,/ Cantelo el caso digalo el suceso/ En el Norte, el Poniente, y el Levante./ La Fè pide ser tuya sin que estorve/ FELIPE DE AUSTRIA el ser tu su defensa, / el Setario, el Infiel, y el Mahometano./ Pues Arbitro de aqueste, y aquel Orbe,/ Para freno, 0 castigo de su ofensa,/ El Rayo pone Dios, y tu la mano" 69.

Desde luego, no podía ser más explícito el Anagrama que Pellicer dedicaba a Felipe IV; el monarca católico era la "Coluna vigilante" de la Iglesia y, claro está, sus actos venian guiados por la mano de Dios, eran diseño de la providencia, para la que la Monarquía era el mejor de los instrumentos: «El Rayo pone Dios, y tu la mano». Poco más podia añadirse.

La Monarquía Católica quedaba pues legitimada para desarrollar su proyecto de dominio universal, un proyecto, por extraño que resulte, no de raíz política, sino religiosa; sólo un poder secular y universal podía defender los intereses espirituales y universales de la Iglesia. Religión por encima de todo. Religión que lo articulaba todo. También el orden político. El monarca hispano podía no reconocer superior en el ámbito secular, pero sí había de reconocerlo en el espiritual; se trataba de una monarquía "in ecclesia», un edificio inserto en un orden mayor religiosamente concebido, una «república civil en el seno de la república eclesiástica» ${ }^{70}$, y sólo en ella adquiría sentido.

69 Ibidem. Anagrama. La misma idea se repite en numerosas ocasiones; así: “...Que la Es paña siempre tuvo por honor,/ el dar a la Iglesia, el triunfo mayor..." (p. 46) o "...Mas Vos, como Palma al peso constante,/ fuysteys de la Iglesia Catolico Atlante..." (p. 49).

70 INUURRITEGUI, J. M., op. cit., p. 17. Del mismo autor, pero más detalladamente, vid., cMonarquía Católica, Recta Ratio, Razón de Estado y Razón de Historia" en La Gracia y la República. El 
Tenemos así, un monarca católico llamado a ser gobernante universal y salvador de la cristiandad. No ha de extrañarnos pues, que fuese el mito de Astrea una de las mejores hormas en que encajar su imagen.

Pero la Monarquía Hispánica no era la única en gozar del especial favor de Dios. Junto con ella, una dinastía había sido designada para colaborar en el plan divino: los Habsburgo. No en vano, la Casa de Austria era la más poderosa de Europa; del poder de su rama hispana ya hemos dado cuenta, mientras su rama austríaca se había convertido en depositaria del título imperial y, pese a los problemas que implicaba la presencia de protestantes en sus dominios, se la reconocía como defensora de los intereses católicos. Precisamente de demostrarlo se encargaba Pellicer en la Fama Austriaca : «...Representare los intereses de que a la Cristiandad se le siguen, de que el Imperio Romano Germanico permanezca en la Augustissima y Potentissima casa de Austria, por ser sola la que en ambas Alemanias, asistida por las fuerças de España, puede hazer resistencia al ceño de los hereges, y a la invasion de los Turcos..." ${ }^{71}$.

Los dos grandes poderes seculares de Europa, el Imperio y la Monarquía Hispánica quedaban encuadrados por una entidad común, la Casa de Austria. Entre sus dos ramas existía, además de un doble vínculo de sangre y jurídico (en la medida en que el rey católico poseía algunos feudos en tierras del Imperio), un lazo derivado de su identidad de fines: la defensa de la religión y la Iglesia católica ${ }^{72}$. Pero aunque ambas ramas se identificasen como pilares de la Iglesia, no todos los autores las situarían en el mismo plano. En este sentido, Pellicer sería una clara muestra de la subordinación de la rama austríaca a la hispana. $Y$ no es que negase las cualidades descritas para la primera, todo lo contrario; de hecho, sus dos panegíricos sobre Fernando II eran símbolo de su reconocimiento hacia ella. Sin embargo, nuestro autor no podía concebir la acción de la misma sin la asistencia de "las fuerças de España" pues, al fin y al cabo, el monarca hispano no sólo era un Austria, sino que gobernaba el edificio temporal, político, elegido por Dios, la Monarquía Hispánica. De este modo, no

lenguaje político de la Teologia católica y el Príncipe Cristiano de Pedro de Ribadeneyra. Madrid, 1998, pp. 171-185. Igualmente sobre la supeditación teológicamente concebida del poder secular al pontífice Vid. Ferraro, D., Itinerari del volontarismo: teologia e politica al tempo di Luis de León. Milán, 1995.

Fama Austriaca..., en Introducción (sin numerar), y fol. 4.

72 Sobre la comprensión del siglo XVil de esta “Comunidad austríaca» Vid. JoVER, J. M. ${ }^{\ddagger}, o p$. cit., pp. 166-173. Sirvan también como ejemplo de la misma las palabras de Felipe de Albornoz: "... Tanto es el empeño de $V$. Magestad en esta materia, [la defensa de la religión] tan antigua en su Casa esta piadosa herencia, que en V. Magestad se continuarà sin duda...", op. cit., fol. 2 (dorso). 
era la identidad dinástica la pieza clave de los planes divinos; jugaba, eso sí, un papel importante, pero no esencial, ya que tal identidad se daba sobre la base de un entendimiento previo (en clave católica) del mundo, que era lo realmente importante. Y la encarnación de tal entendimiento no era la dinastía (aunque pudiese hacer de su defensa su más importante objetivo), sino la Monarquía Hispánica. Mas ya fuese la rama hispana de la dinastía preeminente sobre la austríaca o no, la comunidad de fines reconocida para ambas habilitaba la posibilidad de un proyecto dinástico de dominación, de raigambre religiosa que, como sabemos, los Austrias supieron aprovechar.

La Monarquía era el instrumento indiscutible empleado por Dios en una historia que, asi, se entendía como desarrollo de un plan providencial: la salvación de la humanidad. Los avatares históricos podían entenderse como fruto de la fortuna, pero de una fortuna que, a través de la fe, se convertía en providencia ${ }^{73}$. Pero si el devenir histórico era providencial, poco podían hacer los hombres para entenderlo. La providencia era prácticamente inescrutable a sus ojos, algo dificilmente aprehensible desde la imperfección humana, de ahí que sólo cupiese interpretar el curso de los hechos en términos de señales de agrado o reprobación divina. Al menos dos consecuencias se desprendian de tal forma de interpretar la historia; a la primera ya nos hemos referido y era el especial favor divino que, conforme a esas señales, parecía disfrutar la Monarquía Católica (con las consecuencias político-religiosas que ello implicaba). En cuanto a la segunda, guardaría relación con la utilidad y fines de la Historia como disciplina.

Si la historia se entendía como desarrollo de un plan providencial y la providencia no podía comprenderse, tampoco resultaba posible establecer una relación causal entre los hechos históricos ni, por tanto, interpretarlos como procesos; es decir, la historia no podía ser una forma de explicar el presente pues, en esta percepción de las cosas, pasado y presente eran lo mismo. Pensar el presente en nada difería de pensar el pasado ya que, al menos desde la venida de Cristo, eran todo uno. La España de Felipe IV era lo mismo que la de Felipe III, Carlos V o Alfonso X; era lo mismo que habia sido siempre, el instrumento cristiano de Dios. Mientras de la mano del Humanismo, en otros lugares de Europa parecía desarrollarse una conciencia cada vez más clara de que existía un pasado diferente al

73 Pocock, J. G. A., "The problem and its modes. Providence, Fortune and Virtue", en The Machiavellian moment: Florentine political thought and the Atlantic republican tradition. Princeton, 1975, p. 44. Siguiendo la interpretación de este mismo autor, cuando hablamos de fortuna nos referirnos a la «imperfecta percepción humana de la perfección de la historia» (p. 39). 
momento que se vivía (y justamente porque existía esa conciencia se pretendía recuperar cierta parte del mismo), en la Monarquía Católica las interpretaciones humanistas eran en gran medida distintas ${ }^{74}$. Y era normal; de hecho no podía ser de otra manera, pues sólo si la historia era el plan providencial para la salvación de los hombres, podía tener sentido la existencia de la Monarquía en los términos que venimos viendo.

Esta peculiar comprensión del tiempo, lógicamente habría de repercutir en la propia forma con que los cronistas al servicio de la Monarquia elaboraron el relato histórico. La inexistencia de relaciones causales entre los hechos, enraizada en la visión de la historia como plan providencial, desembocaría en narraciones de carácter fundamentalmente moral que respondian a una dinámica de pecado-castigo-caída y redención; en pocas palabras, una historia explicada como castigo de las malas acciones y premio de las buenas. Pellicer, como cronista, sería buena muestra de ello: "...Purgasteys la España de tales Chimeras,/ con sambenitos, coroças, y hogueras./ El Premio tuvistes del Cielo, infalible,/ cayendo del Norte el Nembrot invencible./ El Eco, Señor deste Acto sagrado,/ a Lutzen llego en la Vala guiado./ Que dando la muerte al Rey de Suecia,/ hizo en la heregia, la Brecha mas rezia..." ${ }^{75}$. Obviamente, el castigo divino hacía de los malos cristianos o de los herejes su principal objetivo y, por tanto, también cuando los monarcas hispanos o sus súbditos no se comportaban como buenos cristianos recibían su justo castigo. Pero no podía olvidarse que la Monarquía Hispánica era el instrumento escogido por Dios para sus planes, gozaba de su especial favor porque, de algún modo, la religión cristiana le era consustancial. De ello se seguía que no podía el castigo llegar al grado de su extinción; habría de quedar siempre un germen, una semiIla, algo que permitiese renacer al pueblo escogido: “Perdiose España, con la invasion de los Moros, por las culpas i Pecados, que refieren...casi todas las Cronicas de España... Salvaronse las Reliquias que escaparon del barbaro Cuchillo, en el abrigo de lo mas fragoso de las Montañas, desde donde començaron a hazer resistencia. En Asturias levantaron por Rey a Don Pelayo..." ${ }^{76}$. España podía perderse, pero no definitivamente; la historia lo demostraba y con ello aportaba una evidencia más sobre su carácter elegido.

\footnotetext{
74 Para una síntesis de las peculiaridades del Humanismo castellano Vid. DI CAMILLO, O., "Humanism in Spain", en RABIL, A. (editor), Renaissance, Humanism foundations, forms and legacy. Vol II. Humanism beyond Italy. Filadelfia, 1988. También en la misma obra Vid. KELLEY, D. R., "Humanism and History", pp. 236-267.

75 Astrea Safica..., p. 53. Idea del Principado..., p. 135.
} 
Por otra parte, si la Monarquía había sido escogida como instrumento divino, por encima de todo, había que conservarla ${ }^{77} \mathrm{y}$, lógicamente, una monarquía gestada en religión, sólo conservando ésta podía conservarse a sí misma. Ya lo decía Salazar: "El principal fundamento que España ha tenido para adquirir los reinos de que goza, y la sólida razón de Estado de que usa para conservarlos, es la Religión» ${ }^{78}$, y no sólo Salazar, también Felipe de Albornoz: "No mantiene las Coronas la razon de estado, sino Dios" ${ }^{79}$ y, claro está, el propio Pellicer: "Es de ignorantes querer establecer las Monarquias, que son Dadivas de Dios, con las cautelas que su providencia aborrece tanto...la exaltacion y aumento de la Honra de Dios...es el Fundamento de la verdadera prudencia, i la verdadera politica..." ${ }^{80}$.

Conservar la Monarquía pasaba por religión; a los hombres, incluido el monarca católico, incapaces de comprender la providencia sólo les quedaba ser buenos cristianos. Y era aquí donde ese peculiar modo de hacer historia que venimos describiendo adquiría su sentido: la historia debía ser y era fuente ejemplar. Con ello se la despojaba de su eje temporal y por ello no cabía distinguir entre pasado y presente.

El fin último de la historia era suministrar a los hombres ejemplos morales que orientasen la rectitud de sus principios cristianos. Pero ¿cómo podía resultar válido el ejemplo de, pongamos por caso, Don Pelayo a un cristiano del XVII? La clave residia en el propio concepto de ejemplo como artificio retórico en el que el tiempo, o más bien la atemporalidad, resultaba ser un elemento esencial. Un ejemplo se definía como la repetición de lo mismo en cualquier momento; no la reproducción o consumación de una figura sino exactamente la figura u original mismo, pues el ejemplo permitía resucitar en cada momento el pasado ${ }^{81}$, no sólo reflejarlo, de ahí su gran poder de persuasión para quienes entendían la historia como un continuum de salvación. En este sentido, nada impedía presentar a Don Pelayo o cualquier otro como ejemplo, ya que precisamente lo ejemplificado era siempre lo mismo. Una historia ejemplar era entonces una historia-

77 El propio Dios, como hemos visto, también lo hacia: “...Cinco vezes ha estado para declinar esta Monarchia, i otras cinco la ha detendido Dios... Algunas perdidas ha avido. Yo lo confiesso, i en mi ASTREA 10 digo. Pero ninguna acontecio por falta de disposicion o providencia...". Astrea Safica..., p. 31.

78 Salazar DE, J., op. cit., p. 53.

79 Felipe de Albornoz, D., op. cit. Fol. 1 (dorso).

3o Pellicer de Ossau, J., Virtudes y vida espiritual de Ferdinando de Austria. Zaragoza, 1640. p. 104 .

B1 Sobre la definición de ejemplo y sus connotaciones Vid. Lyons, J., Exemplum. The Rhetoric of Example in Early Modern France and Italy. Princeton, 1989. De igual modo, para la comprensión del concepto retórico de figura y sus implicaciones Vid. AuErBaCH, E., Figura. Madrid, 1998. 
repetición en la que, por tanto, se eliminaba la tensión temporal; el propio Pellicer lo definía claramente: "...Las Batallas que se han dado desde el principio del Mundo, la Magestad i la Traicion, son tantas que solo ha cavido su comprehension, en la Mente infinita de Dios omnipotente. De las que nos ha dexado, o para Escarmiento o para Exemplo la purisima luz de la Historia, conocemos que todas son de una calidad igual, mudando solo Sujetos, no Designios...” ${ }^{82}$.

Toda la historia era pues repetición ejemplar y precisamente por serlo poseía valor de guía moral. Ese era el contexto en el que cobraban sentido las historias panegíricas al modo de La Astrea Safica o la Fama Austriaca. Se trataba de historias ejemplares, como definía Covarrubias honras "de algún señor particular o persona singular en vida y exemplo» ${ }^{83}$. La Fama Austriaca era así una "Historia panegirica de la exemplar vida, y hechos gloriosos de Ferdinando Segundo...creyendo que en la delineacion sola de su Vida, se pueden producir todas las Maximas necessarias a hazer dichosa toda la razon de Estado..." ${ }^{84}$; incluso ya vimos que el sentido último de hacer una traducción de las Virtudes y vida espiritual de Ferdinando de Austria no había sido otra que ofrecer esa "preciosa semilla de exemplos". Ambas obras pretendian brindar enseñanzas morales, pretensión que aún era más evidente en La Astrea Safica pues, como antes indicamos, originalmente fue dedicada al Príncipe Baltasar Carlos para que le sirviese en su instrucción como futuro monarca: «Puse a sus Reales pies esta obra con semejante inscripcion dedicatoria. SEÑOR. Este breve Elogio de las heroicas Acciones i gloriosas Virtudes que le han adquirido el Renombre de GRANDE, al Rey nuestro Señor padre de V.A. no pedia menos Protector que su esclarecido hijo, en quien logramos las esperanças, de ver imitadas en tan soberana Escuela sus obras admirables: heredando el exemplo con la Corona...” ${ }^{85}$.

Pero no sólo los panegíricos eran historias ejemplares, sino que todas las obras que pretendian incluirse en el ámbito de la historia lo eran. También la ldea del Principado de Cataluña o la Sucession de los Reynos de Portugal i El Algarve tendrían un fin ejemplar, demostrar a catalanes y portugueses su error, tantas veces repetido, para que, como diría Pellicer en la primera de ellas "hallando la senda del Reparo, huyan la

\footnotetext{
B2 Sucession de los Reynos..., p. 7.

83 Covarrubias, S., Tesoro de la Lengua Castellana o Española. Barcelona, 1943

84 Fama Austriaca... en Introducción y título (sin numerar). Fol. 2.

85 Astrea Safica..., p. 23. Es más, en el mismo Argumento de la obra se indica cómo la puso "en manos del llustrissimo i Doctissimo Don luan de Isasi Idiaquez Conde de Pie de Concha. Maestro del Principe nuestro Señor» (p. 25).
} 
del Precipicio» ${ }^{86}$. Justamente por ello, tenía una enorme lógica la realización de obras "históricas" en un momento de crisis como la década de los cuarenta. Catalanes y portugueses no se comportaban como buenos cristianos; nada más oportuno que los ejemplos para recordárselo, pues con el recuerdo debería llegar la enmienda.

La Astrea Safica, la Idea del Principado de Cataluña, la Fama Austriaca... y el resto de obras que Pellicer publicó entre 1640-1642 calcaban pues un mismo discurso de matriz católica e impronta castellana. Tras ello una visión del mundo fundamentada en religión, religión que lo impregnaba todo, que lo ordenaba todo, desde las particulares relaciones entre los hombres, hasta la universal comprensión del papel de la Monarquía y su peculiar historia. Religión como esencia de cada hombre y del conjunto de los hombres. Religión como única forma posible, y por ello excluyente, de entender el mundo. No se trataba de un artificio retórico al servicio de un plan de dominio. El proceso era a la inversa; no era un discurso consecuencia de un plan, sino un plan consecuencia de un discurso que expresaba todo un universo mental religiosamente articulado. $Y$ no podia ser de otro modo. De ello dependía la supervivencia de un edificio político que sólo podía definirse como Monarquía Católica. Lo dijimos antes; era una cuestión de esencia.

\section{BIBLIOGRAFÍA}

AUERBACH, E. Figura. Madrid, 1998.

Bouza Álvarez, F. J. Portugal en la Monarquía Católica (1580-1640). Felipe II, las Cortes de Tomar y la génesis del Portugal Católico. Madrid, 1987.

Clavero, B. Antidora. Antropología católica de la economía moderna. Milán, 1991.

DE ARMAS, F. The return of Astraea: an astral imperial myth in Calderon. Kentucky, 1986.

DI CAMILLO, O. "Humanism in Spain" en RABIL, A. (editor): Renaissance, Humanism foundations, forms and legacy. Vol. II. Humanism beyond Italy. Filadelfia, 1988.

ElLiot, J. «Portugal, Cataluña y la caída del Conde-Duque (1640-1643)» en Historia de España Ramón Menéndez Pidal. Vol. XXV. La España de Felipe IV. Madrid, 1986.

- La rebelión de los catalanes: un estudio sobre la decadencia de España (1598-1640). Madrid, 1977.

FeliPE de Albornoz, D. Cartilla política Christiana. Madrid, 1666.

Fernandez Albaladejo, P. Actas de las Juntas del Reino de Galicia. Vol. II. 1630-1636. Galicia, 1997

- Fragmentos de Monarquía. Madrid, 1992.

- "Católicos antes que ciudadanos: gestación de una "Política Española" en los comienzos de la Edad Moderna", en ForTeA PÉREZ, J. I. (ed.): Imágenes de la diversidad. El Mundo Urbano en la Corona de Castilla (siglos XVI-XVII). Santander, 1997, pp. 103-127.

- “España desde España», en Belenguer, E.; Fernández Albaladejo, P. y Arrieta, J. (eds.). Idea de España. Valencia, 1998

\footnotetext{
${ }^{86} \quad$ Idea del Principado..., p. 4.
} 
Fernandez Albaladejo, P. y Pardos Martinez, J. A. "Castilla, territorio sin Cortes (siglos XVXVII)» en Revista de las Cortes Generales. Núm. 15, 1988.

Ferraro, D. Itinerari del volontarismo: teologia e politica al tempo di Luis de León. Milán, 1995.

Hespanha, A.M. "La senda amorosa del Derecho. Amor y justicia en el discurso jurídico moderno", en PETIT, C. (Editor). Pasiones del jurista. Amor, memoria, melancolía, imaginación. Madrid, 1997.

IÑURRITEGUI, J.M. “Monarquía y Constitución» en Historiar, n. ${ }^{\circ} 1,1999$, pp. 8-18.

- La Gracia y la República. El lenguaje político de la Teología católica y el Príncipe Cristiano de Pedro de Ribadeneyra. Madrid, 1998.

JOVER, J.M. ${ }^{\text {a }}$ 1635. Historia de una polémica y semblanza de una generación. Madrid, 1949.

KeLLEY, D. R. «Humanism and History» en RABIL, A. (editor): Renaissance, Humanism foundations, forms and legacy. Vol. II. Humanism beyond Italy. Filadelfia, 1988, pp. 236-267.

LyONS, J. Exemplum. The Rhetoric of Example in Early Modern France and Italy. Princeton, 1989.

Pellicer de Ossau, J. La Astrea Safica. Panegirico al Gran Monarca delas Españas i Nuevo Mundo en que recopila los Mayores Sucessos de su Felicissimo Reinado, hasta el Año MDCXXXV. Zaragoza, 1641.

- Idea del Principado de Cataluña, recopilacion de sus movimientos antiguos i modernos y examen de sus privilegios. Amberes, 1642.

- Sucession de los Reynos de Portugal i El Algarve. Logroño, 1640.

- Fama Austriaca o Historia panegirica de la vida y hechos del Emperador Ferdinando Segundo. Barcelona, 1641.

- Virtudes y vida espiritual de Ferdinando de Austria. Zaragoza, 1640.

- Biblioteca formada de los libros i obras publicas de Don loseph Pellicer de Ossau y Tobar. Valencia, 1671.

Pocock, J. G. A. The Machiavellian moment: Florentine political thought and the Atlantic republican tradition. Princeton, 1975.

Proclamacion catolica a la Magestad Piadosa de Felipe el Grande Rey de las Españas, y Emperador de las Indias Nuestro Señor. Los Conselleres, y Consejo de Ciento de la Ciudad de Barcelona. 1640.

SalAZAR DE, J. Política española 1619. Madrid, 1997.

SerRA, E. (ed.). La revolució catalana de 1640. Barcelona, 1991.

Simón i TARRÉs, A. Els origens ideologics de la revolució catalana de 1640. Barcelona, 1999.

TANNER, M. The last descendant of Aeneas. The Hapsburgs and the Mythic Image of the Emperor. New Haven, 1992.

TATE, R. Ensayos sobre la historiografia peninsular del siglo xv. Madrid, 1970.

TIERno Galván, E. Avisos históricos. Madrid, 1975.

Valladares, R. Felipe IV y la restauración de Portugal. Málaga, 1994.

- La rebelión de Portugal: guerra, conflicto y poderes en la Monarquía Hispánica (1640-1680). Valladolid, 1998.

VIEjo YharrassarRy, J. "Razón de Estado Católica y Monarquía Hispánica" en Revista de Estudios Políticos (Nueva Época), núm. 104. Abril-junio 1999.

VILLANUEVA, J. "Francisco Calça y el mito de la libertad originaria de Cataluña» en Revista de Historia Jerónimo Zurita, 69-70, 1994.

YATES, F.A. Astraea: the imperial theme in the sixteenth century. Londres, 1985. 